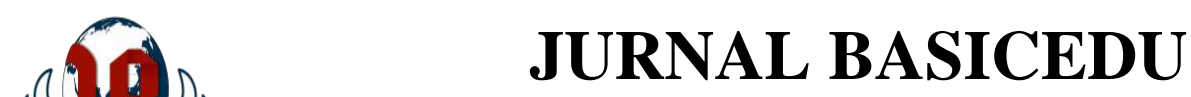

Volume 5 Nomor 4 Tahun 2021 Halaman 1940 - 1945

Research \& Learning in Elementary Education

https://jbasic.org/index.php/basicedu

PATERAWAN

\title{
Pengaruh Penggunaan Media Pembelajaran Video Animasi Berbasis Zoom Meeting terhadap Minat dan Hasil Belajar IPA Siswa Sekolah Dasar
}

\author{
Mayang Ayu Sunami ${ }^{1 凶}$, Aslam $^{2}$ \\ Universitas Muhammadiyah Prof. Dr Hamka, Indonesia ${ }^{1,2}$ \\ E-mail: mayangayu2551@gmail.com ${ }^{1}$, ea_aslam@uhamka.ac.id ${ }^{2}$
}

\begin{abstract}
Abstrak
Di dalam penelitian ini tujuannya untuk melihat apakah ada pengaruh minat belajar peserta didik terhadap penggunaan video animasi dan apakah ada pengaruh peningkatan hasil belajar setelah menggunakan media pembelajaran video animasi. Jumlah populasi totalnya 64 orang dalam penelitian ini, diantaranya VA berjumlah 32 orang dan VB berjumlah 32 orang. Pada penelitian ini, saya memakai metode kuantitatif dengan desain quasi-experimental, khususnya desain kontrol non-equivalent. Setelah dilakukan perhitungan uji normalitas dan homogenitas data tersebut normal dan homogen. Penggunaan media video animasi untuk pembelajaran ada perbedaan yang signifikan antara penggunaan media video animasi dengan media pembelajaran guru biasa gunakan. Hasil belajar menggunakan media pembelajaran video animasi mengalami peningkatan yang sangat baik dari sebelumnya sedangkan penggunaan media yang digunakan guru nilai belajar IPA tetap sama dari sebelumnya karena dilihat selama penelitian siswa kurang aktif dibandingkan dengan kelas yang menggunakan media pembelajaran video animasi. Penggunaan media video animasi membuat minat belajar siswa, dari yang memperhatikan video dan aktif di dalam kelas kemudian mempengaruhi nilai IPA siswa-siswi kelas VA dan VB SDN Kalisari 01, sehingga berdampak baik untuk meningkatkan minat belajar, meningkatkan hasi belajar dari sebelumnya dan sangat membantu dalam pembelajaran secara jarak jauh yang memudahkan membagikan materi pembelajaran dan bisa digunakan kapan saja saat dibutuhkan.
\end{abstract}

Kata Kunci: Video animasi, Minat dan Hasil belajar.

\begin{abstract}
In this study, the purpose was to see if there was an influence of learners' learning interest on the use of animated videos and whether there was an influence on improving learning outcomes after using animated video learning media. The total population was 64 people in this study, including VA numbered 32 people and VB numbered 32 people. In this study, I used quantitative methods with quasi-experimental designs, especially non-equivalent control designs. After the calculation of normality and homogeneity test the data is normal and homogeneous. The use of animated video media for learning there is a significant difference between the use of animated video media and the learning media ordinary teachers use. The results of learning using animated video learning media improved very well than before while the use of media used by teachers of science learning scores remained the same as before because seen during the research students were less active compared to classes that used animated video learning media. The use of animated video media makes students' learning interests, from paying attention to video and being active in the classroom then affecting the science scores of students in va and $v b$ grades of SDN Kalisari 01, thus having a good impact to increase learning interest, improving learning hasi from before and very helpful in learning remotely which facilitates sharing of learning materials and can be used at any time when needed.
\end{abstract}

Keywords: Animated video, interest and learning outcomes

Copyright (c) 2021 Mayang Ayu Sunami, Aslam

$\triangle$ Corresponding author :

Email : mayangayu2551@gmail.com

DOI : https://doi.org/10.31004/basicedu.v5i4.1129

ISSN 2580-3735 (Media Cetak)

ISSN 2580-1147 (Media Online)

Jurnal Basicedu Vol 5 No 4 Tahun 2021

p-ISSN 2580-3735 e-ISSN 2580-1147 
1941 Pengaruh Penggunaan Media Pembelajaran Video Animasi Berbasis Zoom Meeting terhadap Minat dan Hasil Belajar IPA Siswa Sekolah Dasar - Mayang Ayu Sunami, Aslam

DOI: https://doi.org/10.31004/basicedu.v5i4.1129

\section{PENDAHULUAN}

Teknologi mulai berkembang di Indonesia sudah cukup banyak teknologi pembelajaran yang dipakai pada setiap sekolah. guru masih banyak yang tidak memanfaatkan teknologi. Media pembelajaran merupakan sarana untuk memudahkan dalam menyampaikan pembelajaran. sesuai pengamatan selama magang di SDN Kalisari 01 Pagi nilai ipa kelas V cukup rendah karena banyak faktor peserta didik pertama sulit memahami materi pembelajaran, kedua media pembelajaran kurang menarik dan ketiga kurang adanya minat belajar ipa karena peserta didik menganggap sulit. Dengan menggunakan banyak alat atau media pembelajaran yang bisa digunakan seperti visual, audio dan audiovisual. Dalam hal ini melakukan penelitian untuk memberikan gambaran bagaimana cara untuk meningkatkan minat siswa dalam pembelajaran dan nilai yang meningkat dari sebelumnya. Serta memudahkan siswa lebih cepat menerima materi yang diajarkan selama proses belajar, tidak merasa jenuh serta lebih memahami materi yang diajarkan. Dengan Memberikan informasi kepada guru bahwa menggunakan media pembelajaran video animasi dapat digunakan oleh guru untuk memudahkan dalam proses belajar mengajar dengan disesuaikan materi yang cocok.

IPA yaitu mata pelajaran yang wajib di ajarkan di SD karena mempelajari tentang lingkungan sekitar dan aktivitas sehari-hari matapelajaran ini membahas tentang berbagai penemuan, melakukan percobaan dan dikaitkan dengan teori selama proses pembelajaran (Lusidawaty et al., 2020). Karena sangat penting di terapkan untuk siswa SD. Pembelajarn IPA siswa diberikan kesempatan untuk bereksperimen dan mencoba sendiri dan di sesuaikan dengan materi yang diajarkan. Dalam mata pelajaran IPA siswa hanya berpusat kepada guru anak akan merasa bosan dan tidak menyenangkan, seharusnya anak dalam mata pelajaran ini langsung terjun langsung melihat alam sekitar dari hal-hal yang mudah di jangkau. Dalam mengatasi pada saat pembelajaran online bisa menggunakan media pembelajaran. Media merupakan suatu media yang membawa informasi (Wina Sanjaya, 2012) sedangkan media pembelajaran merupakan sarana untuk meningkatkan kegiatan proses belajar mengajar (Kustandi \& Sujipto, 2011). Jadi media pembelajaran yang digunakan adalah video animasi.

Video animasi merupakan alat untuk membantu proses pembelajaran yang berupa gambar yang bergerak seperti hidup (Agustien et al., 2018) sedangkan animasi dapat memberi objek dapat bergerak dan dapat mengubah bentuk, ukuran dan warna (MADCOMS, 2002). Media ini dapat menarik minat, minat merupakan timbulnya dari diri sendiri ingin memperhatikan objek tersebut (Sirait, 2016, p. 37). Kemudian setelah menarik perhatian bisa membuat siswa tertarik secara spontan untuk melihat dan mengamati video animasi tersebut dan munculnya perubahan nilai yang meningkat dari sebelumnya. Hasil belajar merupakan hasil akhir yang mencapai semua komponen dan menguasi matapelajaran yang telah diajarkan (Kusuma et al., 2015). Namun, ketika wabah covid-19 saat ini melanda dunia, kegiatan belajar dapat dilakukan secara online tanpa perlu bertemu di sekolah. Sekolah menggunakan aplikasi Zoom meeting dan WA. Untuk mempermudah berbagi video animasi, peneliti menggunakan Zoom Meeting. Zoom meeting merupakan aplikasi untuk lebih mudah berinteraksi dan melakukan diskusi tanpa harus bertemu (Monica \& Fitriawati, 2020).

Pengamatan pada proses pembelajaran saintifik SDN Kalisari 01 Pagi di Kelas V menunjukkan bahwa minat belajar siswa rendah sehingga mempengaruhi hasil belajarnya. Guru perlu melakukan perubahan untuk memperbaiki media dan bahan ajar. Guru harus lebih kreatif dalam mencari dan mengumpulkan bahan ajar. Melalui penggunaan media video animasi ini untuk membantu guru mencapai tujuan pembelajaran.

Dalam penelitian sebelumnya oleh (Kumala, 2016) dimana dalam kajiannya bahwa penggunaan pembelajaran audio visual animasi sangat berdapat baik terhadap hasil belajar siswa (Aslam et al., 2020). Dalam penelitian lainnya oleh (Sampieri, n.d.) bahwa model pembelajaran dengan menggunakan video animasi lebih efektif daripada model pembelajaran tanpa menggunakan media video animasi terhadap aktivitas belajar siswa. Sedangkan dalam penelitian (Johari et al., 2016) dimana ingin mendapatkan hasil belajar siswa aspek kognitif yang baik pada materi dapat menggunakan media pembelajaran video maupun 
1942 Pengaruh Penggunaan Media Pembelajaran Video Animasi Berbasis Zoom Meeting terhadap Minat dan Hasil Belajar IPA Siswa Sekolah Dasar - Mayang Ayu Sunami, Aslam

DOI: https://doi.org/10.31004/basicedu.v5i4.1129

animasi, sedangkan untuk mendapatkan hasil belajar aspek psikomot dan afektif yang lebih baik menggunakan media video dengan demikian penggunaan media pembelajaran video animasi sangat efektif terhadap peningkatan minat dan hasil belajar siswa sekolah dasar.

Penelitian ini juga menggunakan salah satu media untuk meningkatkan minat dan hasil belajar siswa yaitu menggunakan media pembelajarn video animasi (Adkhar, 2009; Agustien et al., 2018; Jannah, 2017) video animasi adalah salah satu media yang sangat membantu pembelajaran dan dapat menjadi nilai siswa meningkat, sehingga penelitian ini akan diuji pengaruh penggunaan media video animasi berbasis zoom meeting terhadap minat dan hasil belajar IPA siswa kelas V SD.

\section{METODE PENELITIAN}

Penelitian ini termasuk metode kuantitatif deskriptif, yaitu metode eksperimen semu. Metode ini adalah yang pertama untuk menentukan bahwa dua kelas diberikan materi yang sama tetapi ditangani cara yang berbeda. kelas VB sebagai kelas eksperimen diberikan materi siklus air dengan menggunakan media yang dibuat peneliti, sedangkan untuk kelas VA sebagai kelas kontrol diberikan materi siklus air dan menggunakan media pembelajaran yang biasa digunakan guru.

Populasi yaitu suatu wilayah yang terdiri dari objek dengan jumlah dan karakteristik tertentu yang ditetapkan untuk diteliti (Prof.Dr.Sugiyono, n.d.). Dapat disimpulkan bahwa aspek yang ditentukkan peneliti sebagai objek penelitian adalah yang diharapkan oleh peneliti. Maka dari itu, populasinya seluruh siswa kelas VA-VB SDN Kalisari 01 Pagi yang terdaftar pada tahun ajaran 2020/2021. Saat ini ada 64 siswa, termasuk 32 di kelas A dan 32 di kelas B.

Variable penelitian terdapat variabel bebas dan terikat. Media pembelajaran video animasi adalah variabel bebas sementara itu minat dan hasil belajar siswa termasuk variabel terikat. Dilihat berapa besar pengaruh media pembelajaran video animasi terhadap siswa kelas VA-VB. Setelah menggunakan perlakuan, jika terlihat signifikansi (2-tailed) > 0,05 bahwa data yang didapatkan dengan di uji independent sample $t$ test (uji kesamaan mean ganda) analisis standar uji akan menolak Ho dan menerima Ha. Sedangkan jika terdapat Ho diterima dan Ha ditolak.otomatis signifikansi (2-tailed) $<0,05$.

\section{HASIL DAN PEMBAHASAN}

Tabel 1. Hasil Uji Normalitas Data Minat Belajar

\begin{tabular}{llccc}
\hline \multirow{3}{*}{$\begin{array}{l}\text { Minat } \\
\text { belajar }\end{array}$} & Kelas & \multicolumn{3}{c}{ Kolmogrov-smirnov } \\
\cline { 2 - 5 } & & Statistic & df & Sig. \\
\cline { 2 - 5 } & V-B (eksperimen) & 0.110 & 32 & 0,200 \\
\cline { 2 - 5 } & V-A (kontrol) & 0.141 & 32 & 0,108 \\
\hline
\end{tabular}

Tabel ini merangkum hasil perhitungan uji normalitas minat, dan data hasil penelitian terkait minat belajar siswa kelas V SDN Kalisari 01 Pagi. Kelihatan dari nilai (sig.) minat pada kedua kelas berjumlah 0,200 untuk V-B dan pada kelas V-A berjumlah 0,108. Terlihat kedua nilai (sig.) > $(0,05)$. Oleh karena itu, data akan berdistribusi normal.

Tabel 2. Hasil uji Homogenitas Data Minat Belajar

\begin{tabular}{cccccc}
\hline & Levene statistic & df1 & df2 & Sig. \\
\hline Minat belajar & Nilai rata-rata & 1.281 & 1 & 62 & 0,262 \\
\hline
\end{tabular}

Tabel di atas merangkum hasil perhitungan dari nilai (sig.) 0,262 terlihat bahwa data > 0,05 yang menunjukkan mengandung data homogenitas. Berdasarkan analisis data di atas, menggunakan media 
1943 Pengaruh Penggunaan Media Pembelajaran Video Animasi Berbasis Zoom Meeting terhadap Minat dan Hasil Belajar IPA Siswa Sekolah Dasar - Mayang Ayu Sunami, Aslam

DOI: https://doi.org/10.31004/basicedu.v5i4.1129

pembelajaran video animasi berpengaruh terhadap minat belajar siswa membuktikan penggunaan media video animasi berguna terhadap minat belajar siswa kelas V SDN Kalisari 01 Pagi. Dengan penerapan media pembelajaran video animasi, dalam perkembangan teknologi saat ini minat belajar siswa semakin meningkat

Tabel 3. Hasil uji Normalitas Data Hasil Belajar

\begin{tabular}{llccc}
\hline \multirow{4}{*}{ Kelas } & \multicolumn{3}{c}{ Kolmogrov-smirnov } \\
\cline { 2 - 5 } Hasil & & Statistic & df & Sig. \\
\cline { 2 - 5 } belajar & Pretest V-B (eksperimen) & 0.102 & 32 & 0.200 \\
\cline { 2 - 5 } & Posttest V-B(eksperimen) & 0.127 & 32 & 0.200 \\
\cline { 2 - 5 } & Pretest V-A (kontrol) & 0.440 & 32 & 0.111 \\
\cline { 2 - 5 } & Posttest V-A (kontrol) & 0.159 & 32 & 0.038 \\
\hline
\end{tabular}

Tabel di atas menyimpulkan dengan perhitungan uji normalitas, terlihat bahwa hasil (sig.) kedua kelas tersebut lebih besar dari 0,05 Data yang di uji adalah normal. tabel berikut akan membahas hasil uji homogenitas hasil belajar.

Tabel 4. Hasil uji Homogenitas Data Hasil Belajar

\begin{tabular}{cccccc}
\hline \multirow{2}{*}{$\begin{array}{c}\text { Hasil } \\
\text { belajar }\end{array}$} & Nilai rata-rata & Levene statistic & df1 & df2 & Sig. \\
\cline { 3 - 6 } & & 0,981 & 1 & 62 & 0.362 \\
\hline
\end{tabular}

Berdasarkan nilai rata-rata yang tercantum dalam tabel, nilai (sig.) yaitu $0,326<0,05$. kesimpulannya data setiap sampel adalah sama (homogen). Jika diperoleh nilai (sig.) $<0,05$ maka data tersebut homogen. Jika nilai (sig.) $<0,05$ data tidak homogen.

Menentukan bahwa minat belajar siswa muncul karena adanya penggunaan media pembelajaran. Media pembelajaran yaitu alat untuk mempercepat menyampaikan materi dalam pembelajaran (Audia et al., 2021). Salah satunya adalah video animasi yang di rancang semenarik mungkin yang membuat siswa ingin memperhatikan dan memiliki semangat belajar. Video animasi sama seperti audio visual. Audio visual yang menggabungkan antara gambar dan suara (Sari \& Miaz, 2019). Bedanya video animasi di tambahkan animasi yang gambarnya seolah-olah menjadi hidup yang membuat menarik dalam video tersebut. berdasarkan angket kelas eksperimen sangat menyukai penggunaan media pembelajaran video animasi. Akan tetapi kelas yang tidak diberikan media tersebut semangat belajar siswa sama seperti biasa dan setelah di berikan angket minat siswa banyak yang tidak menyukai media pembelajaran video animasi. Mungkin ada beberapa faktor yang mempengaruhinya yaitu siswa tidak tau apa itu media pembelajaran video animasi, kemudian siswa sudah nyaman dengan media yang guru biasa gunakan selama pandemic ini yaitu PPT dan WAG yang menyebabkan kurangnya minat siswa kelas V-A.

Berdasarkan hasi pretest dan posttest kelas V-A dengan menggunakan media yang dipakai oleh guru membuat siswa merasa jenuh yang menyebabkan nilai siswa menjadi rendah dan sama dengan hasil pengamatan sebelumnya tidak ada yang berubah dari sebelumnya. Untuk siswa kelas V-B mengalami perubahan dengan diberikan pretest sebelum diberikan materi pembelajaran dan setelah di berikan materi pembelajaran nilai kelas V-B sangat meningkat. Dalam proses belajar mengajar kelas V-B jauh lebih semangat dan memperhatikan pada peneliti bertanya mengenai pembelajaran respon siswa tersebut langsung menjawab dengan penuh percaya diri.

Hasil dari penelitian ini selaras dengan beberapa artikel yaitu dalam penelitian yang dilakukan oleh Viviantini, Amaram Rede dan Sahrul Saehana dalam penelitian "pengaruh media video pembelajaran terhadap minat dan hasil belajar ipa siswa kelas VI SD" menunjukan adanya perbedaan pengaruh dimana media video animasi lebih berpengaruh dibandingkan dengan media yang biasa guru gunakan (Viviantini, Amram Rede, 2015), sehingga siswa lebih cepat menerima materi pembelajaran. Hubungan penelitian ini bahwa peran 
1944 Pengaruh Penggunaan Media Pembelajaran Video Animasi Berbasis Zoom Meeting terhadap Minat dan Hasil Belajar IPA Siswa Sekolah Dasar - Mayang Ayu Sunami, Aslam

DOI: https://doi.org/10.31004/basicedu.v5i4.1129

media pembelajaran video animasi sangat bagus untuk meningkatkan minat dan hasil belajar. Kemudian dalam penelitian yang dilakukan oleh Selamat Febriadi Ramadhona "pengaruh penggunaan media pembelajaran animasi terhadap minat dan hasil belajar siswa pada mata pelajaran ekonomi di kelas X SMA" menunjukkan perbedaan yang signifikan pada kegiatan pembelajaran (Ramadhona \& Trisnawati, n.d.). Sehingga dalam menggunakan media video animasi dapat berdampak baik dati sebelumnya. Selanjutnya Muhammad Ikhwanul Muslimin mengemukkan dalam penelitiannya yang berjudul "pengaruh penggunaan media pembelajaran video animasi terhadap hasil belajar Pendidikan kewarganegaraan kelas II SD" bahwa penggunaan media pembelajaran video animasi sangat bermanfaat dan berdampak baik dalam proses pembelajaran (M. I. Muslimin, 2012). Namun dalam pengaruh yang baik ini juga masih terdapat keterbatasan terutama pada permasalahan pada penggunaan media pembelajaran video animasi guru harus banyak bersabar dalam mengajarkan, sehingga akan tercapai hasil yang lebih baik.

\section{KESIMPULAN}

Kesimpulannya adalah sebelum siswa kelas V menggunakan media, nilai siswa-siswi kelas VA dan VB cukup rendah dan siswa kurang berminat untuk mempelajari mata pelajaran IPA. Setelah penggunaan media video animasi untuk pembelajaran sangat mempengaruhi minat belajar siswa, dari yang memperhatikan video dan aktif di dalam kelas kemudian mempengaruhi nilai IPA siswa-siswi kelas VA dan VB SDN Kalisari 01, sehingga berdampak baik untuk meningkatkan minat dan menghasilkan nilai -nilai yang memuaskan dan mencapai tujuan pembelajaran.

\section{UCAPAN TERIMA KASIH}

Terima kasih sebelumnya kepada ketua prodi PGSD Ika Yatri, M.Pd dan dosen Aslam, M.Pd atas bimbingannya dalam merampungkan artikel ini. Serta pihak sekolah yang mendukung proses penelitian ini. Berterimakasih pada editor \& reviewer yang sudah memberi saya kesempatan.

\section{DAFTAR PUSTAKA}

Adkhar, B. I. (2009). Pengembangan Media Video Animasi Pembelajaran Berbasis Powtoon Pada Kelas 2 Mata Pelajaran Ilmu Pengetahuan Alam Di SD LABSCHOOL UNNES. Unnes, 544. Http://Lib.Unnes.Ac.Id/23880/

Agustien, R., Umamah, N., \& Sumarno, S. (2018). Pengembangan Media Pembelajaran Video Animasi Dua Dimensi Situs Pekauman Di Bondowoso Dengan Model Addie Mata Pelajaran Sejarah Kelas X IPS. Jurnal Edukasi, 5(1), 19. Https://Doi.Org/10.19184/Jukasi.V5i1.8010

Aslam, Wahab, A. A., Syae Purrohman, P., Zulherman, \& Ampry, E. S. (2020). Internet User Behavior And Social Media In Learning. Proceedings Of The 4th International Conference On Research Of Educational Administration And Management (ICREAM 2020), 526(Icream 2020), 50-55.

Audia, C., Yatri, I., Aslam, Mawani, S., \& Zulherman. (2021). Development Of Smart Card Media For Elementary Students. Journal Of Physics: Conference Series, 1783(1), 012114. Https://Doi.Org/10.1088/1742-6596/1783/1/012114

Jannah, N. (2017). Efektivitas Penggunaan Media Animasi Terhadap Hasil Belajar Siswa Kelas V.

Johari, A., Hasan, S., \& Rakhman, M. (2016). Penerapan Media Video Dan Animasi Pada Materi Memvakum Dan Mengisi Refrigeran Terhadap Hasil Belajar Siswa. Journal Of Mechanical Engineering Education, 1(1), 8. Https://Doi.Org/10.17509/Jmee.V1i1.3731

Kumala, Farida N. (2016). Pembelajaran IPA (Cetakan Pe). Ediide Infografika. 
1945 Pengaruh Penggunaan Media Pembelajaran Video Animasi Berbasis Zoom Meeting terhadap Minat dan Hasil Belajar IPA Siswa Sekolah Dasar - Mayang Ayu Sunami, Aslam

DOI: https://doi.org/10.31004/basicedu.v5i4.1129

Kustandi, C., \& Sujipto, B. (2011). Media Pembelajaran Manual Dan Digital (Asep Jamaludin (Ed.); Pertama). Ghalia Indonesia.

Kusuma, D. H., Wahyuni, S., \& Noviani, L. (2015). Pengembangan Media Pembelajaran Video Tutorial Untuk Meningkatkan Hasil Belajar Siswa. Jurnal Pendidikan Bisnis Dan Ekonomi, 1(1).

Lusidawaty, V., Fitria, Y., Miaz, Y., \& Zikri, A. (2020). Pembelajaran Ipa Dengan Strategi Pembelajaran Inkuiri Untuk Meningkatkan Keterampilan Proses Sains Dan Motivasi Belajar Siswa Di Sekolah Dasar. Jurnal Basicedu, 4(1), 168-174. Https://Doi.Org/10.31004/Basicedu.V4i1.333

M. I. Muslimin. (2012). Pengaruh Penggunaan Media Pembelajaran Video Animasi Terhadap Hasil Belajar Pendidikan Kewarganegaraan Kelas Ii Sd. Jurnal Prodi Teknologi Pendidikan, 6(1), 1-71.

MADCOMS. (2002). Panduan Lengkap Macromedia Flash 5. ANDI.

Monica, J., \& Fitriawati, D. (2020). Efektivitas Penggunaan Aplikasi Zoom Sebagai Media Pembelajaran Online Pada Mahasiswa Saat Pandemi Covid-19 As An Online Learning Medium For Students During The Covid-19 Pandemic. Ejurnal Undana, 1, 1630-1640.

Prof.Dr.Sugiyono. (N.D.). Statistika Untuk Penelitian (28th Ed.). Alfabeta.

Ramadhona, S. F., \& Trisnawati, F. (N.D.). The Influence Of The Use Of Learning Media Animation Of Interest And The Results Of Student Learning On Economic Subjects In Class X Majoring In Social Studies Sma Negeri 1 Kundur Pelajaran Ekonomi Di Kelas X Jurusan Ips Sma. 1-11.

Sampieri, R. H. (N.D.). No 主観的健康感を中心とした在宅高齢者における 健康関連指標に関する共分 散構造分析Title. 634.

Sari, N. N., \& Miaz, Y. (2019). Penggunaan Media Peta Berbasis Multimedia. 3(3), 929-934.

Sirait, E. D. (2016). Pengaruh Minat Belajar Terhadap Prestasi Belajar Matematika. Formatif: Jurnal Ilmiah Pendidikan MIPA, 6(1), 35-43. Https://Doi.Org/10.30998/Formatif.V6i1.750

Viviantini, Amram Rede, S. S. (2015). Pengaruh Media Video Pembelajaran Terhadap Minat Dan Hasil Belajar IPA Siswa Kelas Vi SDN 6 Kayumalue Ngapa. Jurnal Sains Dan Teknologi Tadulako, 4(1), 6671. Http://Jurnal.Untad.Ac.Id/Jurnal/Index.Php/JSTT/Article/Download/6930/5569

Wina Sanjaya. (2012). Media Komunikasi Pembelajaran (Pertama). Kencana. 